\title{
Pedagogical Practices of Code-Switching in EFL Classrooms in Padang, Indonesia
}

\section{Yetti Zainil}

English Department of Faculty of Languages and Arts, Universitas Negeri Padang

\section{Abstract}

This paper presents the investigation on teacher code-switching and their perceptions on effective language teaching and learning in term of their language choice. In this study, Bahasa Indonesia (L2) is the standard language of education and Bahasa Minang is the mother tongue (L1). It was an investigation on two primary EFL classroom in Padang, West Sumatra, Indonesia where the participants most likely to share the same first language and second language. Conversation analysis was used as a tool to quantify and identify the teacher's language use in the video recorded of studentteacher interaction in the classrooms at the first phase; stimulated recall interview

Corresponding Author:

Yetti Zainil

yettizainil@fbs.unp.ac.id

Received: 18 January 2019 Accepted: 24 March 2019 Published: 31 March 2019

Publishing services provided by Knowledge E

(c) Yetti Zainil. This article is distributed under the terms of the Creative Commons

Attribution License, which permits unrestricted use and redistribution provided that the original author and source are credited.

Selection and Peer-review under the responsibility of the First ELEHIC Conference Committee.

\section{G OPEN ACCESS} was used at the second phase to investigate the teacher code switching practices. The main findings revealed the functions of Bahasa Indonesia/English which was used as a means of pedagogical and affective functions such as explaining grammar, motivation and encouragement. This study also revealed that a few Bahasa Minang was used for maintaining teacher and student social distance or closeness. An interesting finding shows that stimulated recall interview technique can foster habits of teachers' self-reflexivity.

Keywords: code-switching, EFL classroom, conversation analysis, stimulated recall interview.

\section{Introduction}

The use of mother tongue or the first language (L1) and code-switching in EFL language classroom has been in pro and contras in recent years. Much research supports the use of L1 in the classroom [1-2]. However, to what extent they support it are still not clearly defined [3]. In the context of Indonesia as well as other country where English as foreign language it is common that teacher and students speak the same language, for example their first language. In this case code-switching often occurs. It is a phenomenon which has been noted for its pedagogical and social applications [1, 4-6]; but the questions 
whether the teacher realizes when, how and why they code-switch has not been clearly answered.

In the context of Padang and Indonesia generally, the lack of guidance of the policy to practice has led teachers to interpret the English curriculum in diverse ways [7]. Therefore, a study is needed to investigate to see to what extent teacher view their codeswitching practices and beliefs about effective language use in teaching and learning process at primary language classrooms.

Moreover, because the teacher and the student share the same mother tongue, language learning become complicated. Due to that circumstances, teachers need to recognize when and why they were using a specific language while giving out the instruction as it will determine whether the student were given chances to hear and use the target language [8-9]. In the current practices only 70 minutes of English instructions allocated for the students and this is the only time when the students were expose to the TL as the language input. Furthermore, there is no English curriculum at any level in Indonesia which prescribe coherently in how much language exposure should the teacher have, even though the use of English is encourage in the curriculum document. Besides, the national curriculum will not be the same one to another as it is developed and interpreted on each level of province, be it the function and the tool [10].

According to [29] the use of mother tongue (L1) has both advantages as well as disadvantages because of what it can help teachers with its richness of the existing mother tongue knowledge; but if it is overused the mother tongue may limit potential target language uptake. This article is a response to some findings of Cook [1], Inbar-Lourie [8], Polio \& Duff [9] research. They supported the claim that teachers did not realized what time and reasons they switched code. They also discussed that many teachers regard the usefulness of the use of first language or mother tongue (L1) in their teaching [11-13]. It is worth noting the absence of guidelines for teachers on the appropriate balance of language use in the context of my research resulting in teacher's code-switching on an ad hoc basis.

\section{Teachers' Code-Switching in the EFL Classroom}

Research on language behavior which is known as code-switching shows that codeswitching might happened when the speakers share the same language [14]. Garcia \& Wei [15] defined code-switching as a simple shift between codes or languages; it is a common language behaviour that also happens in a language classroom if teachers and learners share the same language/languages (Lo, 2015). 
Following [16], in this study, code-switching is used as the term to preserve the binaries as mother tongue or first language is seen as mediating the foreign language [2]. Accordingly, it functions as the educational tool. Arnfast \& Jorgensen [17] explain that code-switching is a systematic use of L1 and L2 in the conversation or utterances; and it is regarded as a competence which allow bilingual speakers to compromise fluently.

Furthermore, Edmonson [8] discusses that code-switching is more frequently defined as the language use of bilinguals/multilinguals therefore in the context of classroom research switching between one language and another is not often regarded as codeswitching. Research shows that in naturalistic contexts some code-switching happened to let the communication flow as well linguistic development [19], because the participants do not have the same amount of understanding of both languages. Because switching between languages considered as a result of lack abilities in the classroom teaching, therefore the thought of using code switching in L2/EFL is unaccepted in the traditional classroom settings [20].

In contrast to [19] and [20] above, recent studies in multilingualism found out the affirmative effects of code-switching by the teacher in classroom discourse [1, 16, 21-24]. In line with these researches, Lo [2] found that insight shifting of the role play in learning foreign languages beginning to show its effect on the classrooms practice. Shuchi \& Islam [25] propose that "a judicious and moderate use of L1 does not hinder learning; rather, it assists, aids and facilitates the teaching and learning process thus providing the teacher with an effective pedagogical tool for maximizing the learning outcomes".

Macaro [13] concludes that "code- switching by the teacher has no negative impact on the quantity of students' $L 2$ production and that 'Expert code-switching' may actually increase and improve it". Furthermore, researchers believe that teachers will most likely to use the first language especially when they share the same first language (Bozorgian \& Fallahpour, 2015) [14, 26].

This paper will mainly discuss how the teacher of EFL classrooms code-switch during their teaching by analyzing the classroom observations using conversation analysis as well as analyzing teacher perceptions using stimulate recall interview.

\section{Method}

This case study used a qualitative research designs which focuses on three teachers. Three teachers with their respective classes in two primary schools in Kota Padang, West Sumatra, Indonesia were observed in order to answer the following research question: 
- To what extent teachers' code switch and what are the pedagogical and affective functions of their code-switching in the EFL classroom in Padang, Indonesian context?

I undertook two phases of a qualitative analysis of code-switching in the classroom. For the first phase, Conversation Analysis (CA) were used as a tool for coding the data based on transcripts of teacher talk in the observed 10 lessons. These observed lessons were video recorded. Then for the second phase, stimulated recall interview with the teacher were used to find out the teachers' understanding and beliefs on their code switching. The use of both conversation analysis and stimulated recall interview with teachers in this study is important based on the reason that conversation analysis can provide some evidence of functions of teachers' code-switching and stimulated recall interview clarifies those evidence. These stimulated recall interviews were audiorecorded.

In the current studies, there are two reasons why the stimulated recall interview used: to explore the teachers' reason for code switching at a specific time on their teaching as well as to trigger their teachers to reflect on their practice. It was a semi-structured interview. A set of questions guiding the interview was used while the teachers watching the video recording of their teaching. The researcher asked teachers the reason they believed on their language choice during their interaction with their students, why they used Bahasa Minang/Bahasa Indonesia or English in certain instances in their teaching. In addition, the researcher also asked the teachers what their general teaching philosophy was in relation to their code-switching in the classroom.

\section{Results and Discussion}

Overall as it happened in the other EFL classrooms where the teachers and the students speak the same language/languages, the three teachers in this study employed a variety of code-switching in their teaching. In this research contexts, classes were started with greetings from the teacher with an Arabic word 'as-salamu alaykum' which mean 'peace be upon you' and this was also answer in Arabic by the students. Having most Minangkabau people or West Sumatra as a Muslim (almost 100\%), these expressions are commonly used in for their faith. After that, the observed classes exchange another greeting in English, which is 'Good morning'.

It seemed that the three teachers described their code-switching in terms of both pedagogical and affective reasons, paralleling to an extent the observation data. More time effective was the main reason Teacher A said for her switching code. The opposite 
reason was given by Teacher B and C, they said they used Bahasa Indonesia just to give instructions and explaining the structure of the sentence to the students.

An interesting finding that emerged in this study was the issue of the teachers' awareness of their own code-switching. Excerpts of data from the transcripts of the classrooms observations and stimulated recall interviews are presented below to build an in-depth understanding of the teachers' language use and the reasons for their code-switching.

\subsection{Awareness of switch repetition}

Switch repetition was one of the interesting findings of this study. It is a term to describe for what happened when teacher uttered in one language which then translated it into another language. This switch repetition was used by teachers in this study in different ways, for example with differing initial language choices; they claimed differing reasons for its use.

Switch repetition done by teacher A happened often from English to Indonesian. Almost of her teaching is related to the vocabulary of teaching, for example asking the translation of a specific word to students. She was still code-switching although her remarks in English was quite understandable. On a stimulated recall interview, she claimed that it was spontaneous, was the reason why she translating her words from English to Indonesia. She gave reasons this as "untuk menghemat waktu" [to save time], but the result of the video recording of classroom interaction transcript analysis shows that students were not given enough time to check the students' comprehension before switching. It seemed that she was not aware of her code-switching. It was unclear as if the teacher is aware or unaware that she was code-switching. However, switch repetition did not occur from Bahasa Indonesia to English on the teacher's utterances.

In contrast with Teacher A, Teacher B code-switch her utterance from English to Indonesian as well as Indonesian to English. Teacher B explained the reason she used Bahasa Indonesia initially before English in order to check whether the students know the word "matahari" is sunlight. She wanted the student be able to give the answer to her vocabulary questions as she already mentioned it in Bahasa Indonesia.

Teacher $\mathrm{C}$ admitted that she learned much after watching her video. She commented and mentioned in the stimulated recall interview she was surprised looking at how she code-switched during her lesson. After seeing video of her teaching, Teacher A mentioned that she saw her continuously using Bahasa Indonesia after her target language. She commented that it was not necessary to do that. 
The paragraph below provides a clear critical reflection development and it shows that seeing her video allow the teacher to see fairly of their teaching.

Sometimes we spoil the students, right mam? I repeat even the simple one. I repeat it in Bahasa Indonesia. It might be insignificant, but sometimes I do it spontaneously without realizing it. (C, 03-03, 13)

The first main finding, based on the analysis of video recording of classroom interaction transcript, was that the three teachers did code-switching in their classrooms for different reasons, however they were not certain the reason they are doing so. After looking at the study context, an Indonesian- based elementary school, I figure that it was because it was an exam focus as the main reason why the teachers were using code switching. It was in order to accommodate the students with the chance to communicate and boost their comprehensions. Furthermore, following Cook [1] the pedagogical and the affective were considered as two main categories of teachers' code-switching. It seemed that teachers code-switched intentionally in saving time, teaching grammar helping the low-achiever students and attaining instructional goals.

It is understandable that the teacher participants were refraining themselves from a long English explanation by using Bahasa Indonesia. Teachers were using their first language to teach EFL so that they will be able to cover the content of their curriculum in a specific time frame. Along with Crawford [27], the result of this study shows that the teachers feel that using their mother tongue was more practical than using English as the target language. 'Spontaneous' circumstances also aided their increasing awareness of their intrinsic motivation. The exhibited way of teaching the grammar in a deductive way considered improper for young learners as mentioned by Nedomova [28].

In the stimulated recall interview teachers shows a conflicting term between the comparisons of the purpose of code-switching found in the lessons and the reasons referred by the teachers. In the teachers' professional development, these disagreement needs to be accepted and pointed out. In the stimulated interview, teachers shows an unawareness that they were code-switching unintentionally.

\subsection{Lack of awareness of language choices}

The second important finding of this study is that stimulated recall interview is a very beneficial device in either the teacher education or continuous professional learning. This study revealed that the use of Bahasa Indonesia in teaching and learning process 
classrooms was helpful; however this study also revealed that teachers was not fully aware how beneficial it is in facilitating the language learning.

The three teachers recognized that it was useful that they could watch video recording of their performance in class especially on their use of language or their language choices. They mentioned they did not realize that they often used Bahasa Indonesia during their teaching and regarded it as a 'spontaneous' action. Their reactions at the end of the interview indicate that they were surprised when they noticed that they were doing code-switching.

As the students are quiet I realize that they didn't understand what l'm saying, so spontaneously I spoke in Bahasa Indonesia. And it seems to me that it works well. (A, 02-03, 13)

Teacher A comment above shows that there was a stimulus - the judgment that her students silence signified lack of understanding therefore Teacher A's response was spontaneous in the sense of being unconscious and automatic. It perhaps reflected her confidence in her teaching experience and awareness of good language learning practices.

Despite realizing its necessities, they said that they occasionally translate English to Bahasa Indonesia.

Sometimes I tend to translate, well (laughing), it should not be necessary. (A, 02-03, 13)

Findings suggest that those teachers only realized their code-switched after watching themselves teaching in stimulated recall interview. This suggests that stimulated recall interview techniques are of value for language teacher professional development. They foster habits of self-reflexivity.

Teacher $C$ who seemed to have a lowest proficiency in English among the three teachers admitted a certain lack of confidence in the stimulated recall interview herself. This suggested the reasons why she alternated her language the most among the participants in this research. This teacher finished her study from a low-ranking private university before becoming a teacher. As in many contexts, in Indonesia, institutional prestige is highly influential. It may not mean that the teacher education course was in any real sense deficient. Teacher $C$ mentioned in the stimulated recall interview that her environment preventing her for speaking English outside the classroom; She will be considered showing off if she used English outside the classroom. 


\section{Conclusion}

Overall, this study has identified pedagogical functions and affective functions of codeswitching as a result of analyzing lesson and stimulated recall interview transcripts. Conversation analysis was used to locate the pedagogical and affective functions of codeswitching; stimulated recall interview was used to see whether teacher's pedagogical and affective observed functions of code-switching in accordance with their view on their code-switching practices.

Furthermore, this study revealed that to teach grammar, to explain new vocabulary (translation), to help students to focus, to maintain the flow of the lesson, checking comprehension, confirmation check, and concept checking were the pedagogical functions of teacher's code switching. To accommodate the limited English proficiency of their students, to motivate students, to build good rapport with students regarded as affective functions.

In conclusion, this study found that the experience of watching themselves teaching during the stimulated recall interview is a powerful agent for change for teachers. They only realized their language choices only after experiencing the stimulated recall interview. They had not previously considered it. This complex picture of language use in the classroom needs to be better understood in order to improve the Indonesian languageteaching curriculum.

\section{References}

[1] Cook, V. (2001). Using the first language in the classroom. Canadian Modern Language Review, 57(3), 402-423.

[2] Lo, Y. Y. (2015). How much L1 is too much? Teachers' language use in response to students' abilities and classroom interaction in Content and Language Integrated Learning. International Journal of Bilingual Education and Bilingualism, 18(3), 270288.

[3] Waer, H. H. E. (2012). Why that language, in that context, right now? The use of the L1 in L2 classroom interaction in an Egyptian setting. Unpublished Ph.D Thesis, School of Education, Communication, and Language Sciences: Newcastle University.

[4] Canagarajah, A.S. (1995). Functions of codeswitching in ESL classroom: socializing bilingualism in Jaffna. Journal of Multilingual and Multicultural Development, 6, 173195. 
[5] Hidayati, I. N. (2012). Evaluating the role of L1in teaching receptive skills and grammar in EFL classes. CONAPLIN JPURNAL Indonesian Journal of Applied Linguistics, 1(2), 17-32.

[6] Turnbull, M. \& Arnett, K. (2002). Teachers' uses of the target and first language in second and foreign language classroom. Annual Review of Applied Linguistics, 22, 204-218.

[7] Depdiknas RI (Department of Education Republic of Indonesia). (2006). KurikuIum Tingkat Satuan Pendidikan Bahasa Inggris untuk SD/MI (KTSP) (School Based English Curriculum for Elementary School). Jakarta: Departemen Pendidikan Nasional.

[8] Inbar-Lourie, O. (2010). English only? The Linguistic choices of teachers of young EFL learners. International Journal of Bilingualism, 14, 351-367.

[9] Polio, C. G \& Duff, P. A. (1994). Teachers' language use in university foreign language classrooms: A qualitative analysis of English and target language alternation. The Modern Language Journal 78(3), 313-326.

[10] Suyanto, K. E. S. (2003). Qualification on EYL teachers in some regions in Indonesia. Paper presented at the International Conference TEFLIN. Bandung: October, 21-23.

[11] Juarez, C., \& Oxbrow, G. (2008). L1 in the EFL classroom: More a help than hindrance. Porta Linguarum, 9, 93-109.

[12] Macaro, E. (1997). Target language, collaborative learning and autonomy. Clevedon: Multilingual Matters.

[13] Macaro, E. (2009). Teacher use of codeswitching in the second language classroom: Exploring 'optimal' use. In M. Turnbull \& J. Dailey-O'Cain (Eds.). First language use in second and foreign language learning (pp. 35-49). Bristol: Multilingual Matters.

[14] Raschka, C., Sercombe, P., \& Chi-Ling, H. (2009). Conflict and tensions in code switching in a Taiwanese EFL classroom. International Journal of Bilingual Education and Bilingualism, 12(2), 157-171.

[15] Garcia \& Wei. (2014). Translanguaging: Language, Bilingualism, and Education. New York, NY: Palgrave MacMillan.

[16] Yıld $ı$, M. \& Yeșilyurt, S. (2017). Use or Avoid? The Perceptions of Prospective English Teachers inTurkey about L1 Use in English Classes. English Language Teaching, 10(1), 84-96.

[17] Arnfast, J.S. \& Jorgensen, J. N. (2003). Code-switching as a communication, learning, and social negotiation strategy in first-year learners of Danish. International Journal of Applied Linguistics, 13(1), 23-53. 
[18] Edmonson, W. (2004). Code-switching and world-switching in foreign language classroom discourse. In J. House \& J. Rehbein. Multilingual Communication (pp. 155178). Philadelphia:John Benjamin B.V.

[19] David, A. (2004). The developing bilingual lexicon. Unpublished doctoral dissertation.University of Newcastle, UK.

[20] Winford, D. (2003). An introduction to contact linguistics. Oxford: Blackwell Publishing Ltd.

[21] Atkinson, D. (1987). The mother tongue in the classroom: A neglected resource. English Language Teaching Journal, 41(4), 241-247.

[22] Barani, G. \& Fatemi, A. H. (2014). The impact of' teachers' codeswitching on the vocabulary learning of Iranian University EFL learners. Journal of Language Sciences \& Linguistics 2(4), 91-98.

[23] Caukill, E. J. A. (2015). The influence of Bis/ama on lexical choices in children's written English: A case study in Vanuatu. Unpublished: PhD. Dissertation, Queensland University of Technology.

[24] Sato, R, (2016). Examining Japanese use of teacher's use of L1 in English classes: Frequency, function and reason behind them. Master thesis: Nara University of Education.

[25] Shuchi, I.J \& Islam, A.B.M.S. (2016). Teachers' and Students' Attitudes towards L1 Use in EFL Classrooms in the Contexts of Bangladesh and Saudi Arabia. English Language Teaching, 9(12), 63-73.

[26] Rassaei, E. (2012). The Effects of Input-based and Output-based Instruction on L2 Development. The Electronic journal for English as a Second Language, 16(3), 1-25.

[27] Crawford, J. C. (2004). Language choices in the foreign language classroom: Target language or the learner's first language? RELC, 35(1), 5-20.

[28] Nedomová, A. (2007). Teaching grammar to young learner. Unpublished bachelor thesis, Masaryk University, Crech Republic. Retrieved from http://is.muni.cz/th/44537/ pedf_b/bachelor_thesis.pdf

[29] Zainil, Y. (2017). Stimulated Recall: Unpacking Pedagogical Practices of Codeswitching in Indonesia (Published Dissertation). Melbourne: Deakin University Australia. 